\title{
Conservative Treatment of Chronic Osteomyelitis Associated with Florid Osseous Dysplasia
}

\author{
Tratamiento Conservador de Osteomielitis Crónica Asociada con Displasia Ósea Florida
}

Wilson Gustavo Cral'; Rosana Adami Tucunduva²; Jose Humberto Damante ${ }^{3}$ Renato Yassutaka Faria Yaedú ${ }^{3}$; Mariana
Quirino Silveira Soares ${ }^{4}$; Ana Lúcia Alvares Capelozza ${ }^{3}$; Denise Tostes Oliveira ${ }^{3} \&$ Cassia Maria Fischer Rubira $^{3}$

CRAL, W. G.; TUCUNDUVA, R. A.; DAMANTE, J. H.; YAEDÚ, R. Y. F.; SOARES, M. Q. S.; CAPELOZZA, A. L. A.; OLIVEIRA, D. T. \& RUBIRA, C. M. F. Conservative treatment of chronic osteomyelitis associated with florid osseous dysplasia. Int. J. Odontostomat., 13(3):275-278, 2019.

ABSTRACT: Florid osseous dysplasia (FOD) is an extensive form of osseous dysplasia where normal trabecular bone is substituted by fibrous connective tissue and amorphous mineralized tissue. Usually, the lesions are mainly asymptomatic and the patients should be followed with clinical and imaging examination, requiring no intervention. Nevertheless, due to the poor vascularization of the lesion and local trauma, secondary infections and osteomyelitis may occur. Patients may present with pain, mucosal ulceration, and lesion exposure in the oral cavity, fistula and swelling. In such cases, correct diagnosis and management of the lesion is decisive to reestablish patient's health and quality of life. The aim of this article is to present a case of complicating secondary chronic osteomyelitis treated successfully with conservative intervention. A 68-year-old black female patient reported a "swelling of the gums" that was present for eleven years, with episodes of periodic pain and swelling. On physical examination, a papule with suppuration in the alveolar mucosa in the right side of the mandible was observed. Panoramic radiography and CBCT showed a mixed lesion surrounded by sclerotic bone. The patient was diagnosed with chronic osteomyelitis in association with FOD and treated with antibiotic therapy together with surgical curettage. The incidence, etiophatology, differential diagnosis, treatment and prevention of secondary osteomyelitis associated with FOD are discussed in the light of literature. This information might assist the dentists while choosing the best treatment options for similar cases.

KEY WORDS: bone diseases; osteomyelitis; diagnostic imaging.

\section{INTRODUCTION}

Benign Fibro-osseous lesions (BFOL) are a group of conditions with similar histological features where normal bone is replaced with a fibrous connective tissue with different degrees of mineralization. Each BFOL subtype presents unique demographic, clinical and radiologic characteristics (de Noronha Santos Netto et al., 2013). Osseous dysplasias (OD) are the most common BFOL of the jaws (de Noronha Santos Netto et al.; Abramovitch \& Rice, 2016). The World Health Organization (WHO) refers to these conditions as "osseous dysplasia" and recognizes the term "cementum-osseous dysplasia" as a synonym (Barnes et al., 2005).
OD have been designated according to their features, as periapical, focal, florid or familial gigantiform cementoma (FGC). Florid osseous dysplasia (FOD) was first described by Melrose et al. (1976) as an exuberant form of OD characterized by the presence of multiple, diffuse, lobular or irregularshaped radiopacities throughout the alveolar processes, but not restricted to the root apices. FOD has a remarkable tendency to bilateralism, usually, with symmetrical lesions and can involve all quadrants (Barnes et al.; Sadda \& Phelan, 2014). Simple bone cists concomitant occurrence had also been reported. Cortical bone expansion may be present, however

\footnotetext{
${ }^{1}$ Stomatology Master's - Department of Stomatology, Bauru School of Dentistry, University of São Paulo, Bauru, São Paulo, Brazil.

${ }^{2}$ PhD Student - Department of Stomatology, Bauru School of Dentistry, University of São Paulo, Bauru, São Paulo, Brazil.

${ }^{3}$ Associate professor - Department of Stomatology, Bauru School of Dentistry, University of São Paulo, Bauru, São Paulo, Brazil.

${ }^{4} \mathrm{PhD}$ - Department of Stomatology, Bauru School of Dentistry, University of São Paulo, Bauru, São Paulo, Brazil.
} 
external visible facial asymmetry is usually not observed (Melrose et al.).

Characteristically, FOD affects middle-aged black females (Barnes et al.). In the majority of the cases, no symptoms are present and the lesions are identified when radiographs are taken for other causes (Barnes et al.; Alsufyani \& Lam, 2011). The diagnosis of FOD should be carried out with clinical and imaging evaluation, which provides essential information for the correct selection of treatment (MacDonald-Jankowski, 2004). In fact, biopsy should be avoided in asymptomatic lesions because of the risk of infection and fracture. The surgical removal of the lesions is also not justified since it would involve extensive intervention and FOD lesions are self-limiting (Dagistan et al., 2007; Alsufyani \& Lam; Kutluay Köklü et al., 2013).

FOD management depends on the presence of symptoms and no treatment is required unless the lesion becomes secondary infected. When symptoms of infection are present, aggressive curettage should be done, removing the dead tissue. In Asymptomatic lesions clinical and radiographic follow-up should be carried out (Sadda \& Phelan). The aim of this article is to report a case of conservative treatment with antibiotics and curettage of a secondary chronic osteomyelitis in a patient with FOD.

\section{CASE REPORT}

A 68-year-old black female patient with a complaint of "swelling in the gums" was referred to the Department of Surgery, Pathology, Radiology and Stomatology at Bauru School of Dentistry. The lesion had been present for 11 years, with episodes of periodic pain and swelling. The patient also reported having undergone three previous surgical interventions in the jaws. Her medical and family history were not remarkable. The intraoral examination revealed the presence of a $1 \mathrm{~mm}$ of size papule, bleeding when touch and showing suppuration in the alveolar mucosa in the right side off the mandible. The patient was toothless and had been using tissue-borne prosthesis (Fig. 1).

A panoramic radiography showed multiple irregular and diffuse radiodense masses in maxilla and mandible (Fig. 2). In the posterior region on the right side of the mandible, a radiopaque and radiolucent lesion was observed (arrow). The radiographic images correspond to the area of intraoral fistula.

Cone Beam computed tomography revealed mixed hypodense/hyperdense lesion with discontinuation of alveolar bone cortical (arrow) surrounded by sclerotic trabecular bone involving the posterior region of the right mandible. Hyperdense masses were also observed in the right and left maxilla. No cortical bone destruction or expansion was noticed (Fig. 3). In the light of clinical and imaging findings we stablished the diagnosis of chronic osteomyelitis in association with FOD.

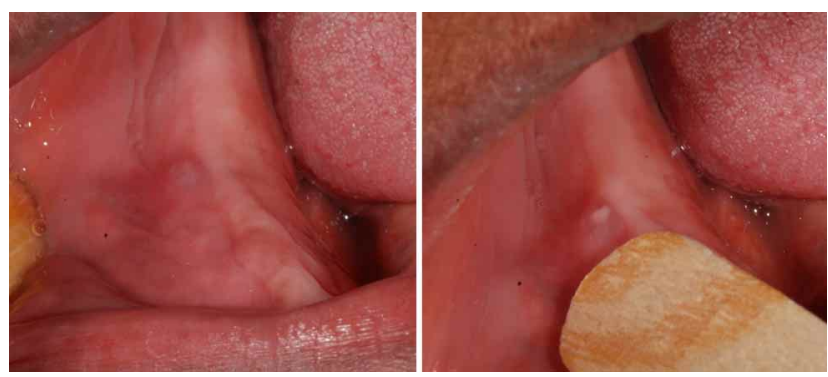

Fig. 1. Fistula in the alveolar region of the posterior mandible.

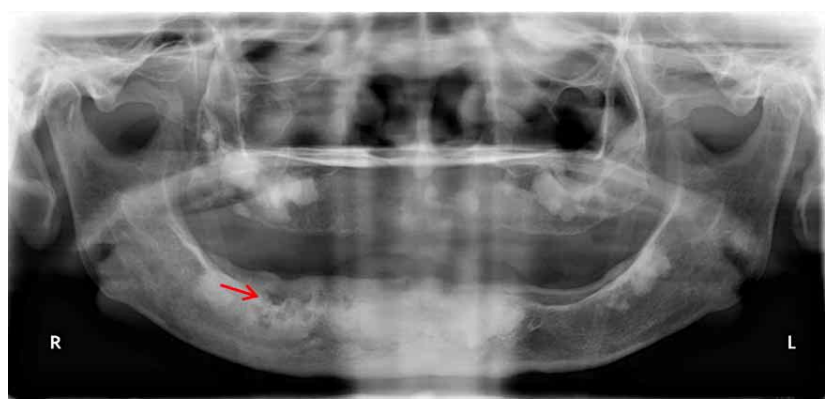

Fig. 2. Multiple Amorphous extensive radiopaque lesions in all quadrants. In the posterior region of the mandible on the right side a mixed legion with irregular-shaped radiolucent areas is observed (arrow).

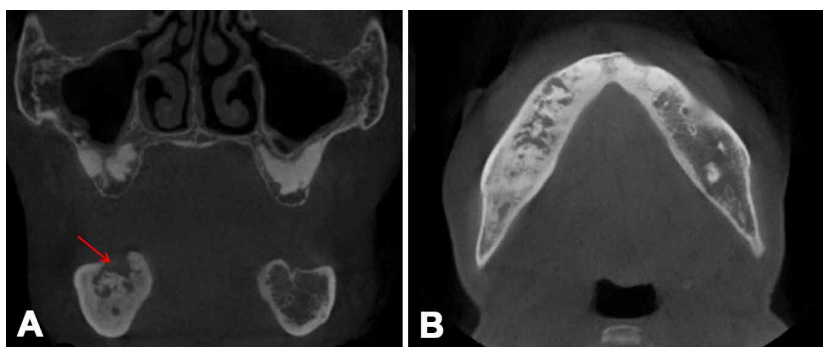

Fig. 3. a. Coronal reconstruction showing amorphous hyperdense images in the maxilla. In the right mandible the presence of mixed lesion presenting hipodense areas with discontinuity of the alveolar bone cortex (arrow) surrounded by sclerotic trabecular bone is observed. b. Axial reconstruction showing diffuse mixed hyperdense/hypodense lesions in mandible. 
An antibiotic therapy was carried with clindamycin $300 \mathrm{mg}$, four times, daily. After seven days of antibiotic therapy the surgical intervention was performed. Under local anesthesia the necrotic bone was removed by surgical curettage. The oral surgical soft tissue was submitted to histopathologic examination. The examined section features correlated with fistula containing intense chronic inflammatory infiltrate. The antibiotic prescription was maintained for 5 days after surgery. The patient has been followedup and no sign of recurrence have been observed during one year.

\section{DISCUSSION}

Usually, FOD is an asymptomatic benign condition and no treatment is required (Sadda \& Phelan). However, secondary infection may occur with pain, mucosal ulceration, exposure of bone, fistula and swelling (Bencharit et al., 2003). In this article we present a case of chronic osteomyelitis in an edentulous patient conservatively treated with antibiotics and surgical curettage.

The development of low-grade osteomyelitis in edentulous areas is pointed by (Melrose et al.) as the principal complication of FOD. It is believed that FOD avascular nature contribute to the susceptibility to infection (Sadda \& Phelan). Alsufyani \& Lam investigated 118 cases of bone dysplasia treated between 1990 and 2007 . Twenty five $(21.2 \%)$ were diagnosed with FOD and 93 cases $(78.8 \%)$ were periapical osseous dysplasia. Osteomyelitis was present in $6(24 \%)$ of the patients with FOD and in 7 $(8.8 \%)$ of the patients with periapical osseous dysplasia (Alsufyani \& Lam). This higher incidence of osteomyelitis associated to FOD is probably due to the fact that FOD produces larger and more diffuse areas of sclerotic mineral tissue when compared to periapical bone dysplasia.

Some radiographic and clinical aspects should be considered to perform the differential diagnosis of FOD and other conditions like periapical and focal osseous dysplasias, fibrous dysplasia, familial gigantiform cementoma, Paget's disease, chronic diffuse sclerosing osteomyelitis and osteosarcoma (Melrose et al.). In the present case due to the diffuse presentation of the lesions and the presence of osteomyelitis, we emphasize the importance of FOD differential diagnosis with FGC, Paget's disease and chronic diffuse sclerosing osteomyelitis (CDSO) (Schneider \& Mesa, 1990; Sarmento et al., 2013). FGC is characterized by an autosomal dominant inheritance with variable expression with a history of familial involvement. Usually FGC acomits young Caucasian patients and presents jaw bone expansion, Paget's disease and FOD present similar radiographic features, however Paget's disease is characterized by entire mandible involvement, loss of lamina dura, deformities of multiple bones and biochemical serum changes, such as elevated alkaline phosphate levels (Kutluay Köklü et al.; Sarmento et al.). In CDSO the lesion is usually present in one site of the mandible, and the lesions are first an inflammatory process presenting swelling and tenderness of the mandible. Radiographically, CDSO appears as a single poorly delineated opaque segment of the mandible and the lesion can involve from the alveolus to the inferior margin and may extend into the ramus. Furthermore, middle-aged black women are not particular susceptible to CDSO (Schneider \& Mesa).

It has been demonstrated that osteomyelitis of the jaws are usually associated to mixed anaerobic infections caused by oral microorganisms (GaettiJardim Júnior et al., 2010). In the present article, the atrophy of the alveolar ridge associated with local trauma of the prosthesis and secondary infection by the oral microorganisms are probably the main etiopathogenic factors of the osteomyelitis lesion.

Clindamycin is a lincosamide antibiotic that acts inhibiting bacterial protein synthesis (Smieja, 1998). It has excellent oral bioavailability, bone penetration and is generally active against most anaerobes. Hence, it represents an interesting choice for the antibiotic treatment of osteomyelitis of the jaw 15. Nevertheless, due to the poor tissue diffusion in FOD lesions, complicating osteomyelitis conservative treatment only with antibiotics may be insufficient, thus surgical debridement, curettage, sequestrectomy or, in more severe cases, resection may also be required (Kutluay Köklü et al.; Das et al., 2013; Sadda \& Phelan). In the case presented, osteomyelitis did not involve the entire FOD lesion. As the FOD lesion affected an extensive area of the mandible, complete resection would not be recommended, since it would lead to a big defect and morbidity. So, we opted for the conservative treatment with clindamycin, surgical exposure of the necrotic bone with curettage and follow-up.

The risk of delayed alveoli healing and bone sequestration after dental extraction in patients with 
FOD have been reported (More et al., 2012). Therefore, in asymptomatic patients with FOD, in order to prevent secondary infection and osteomyelitis, periodical followup with prophylactic management for periodontal diseases and caries to avoid the need for extractions should be carried (Sadda \& Phelan). Pulpar necrosis should also be prevented as the endodontic treatment may push bacteria to the periapex starting an osteomyelitis (Schneider et al., 1987). Dental rehabilitation is also challenging in patients with FOD. In edentulous patients, while the normal alveolar bone undergoes atrophy the sclerotic masses remain, and local trauma of the tissue-borne dentures can lead to secondary infections of FOD lesions. Additionally, due to the compromised vascularization and plasticity of the cancellous bone, implants osseointegration might be impaired (Sadda \& Phelan; Oliveira et al., 2014). Orthodontic treatment may also impair in complications and should be carried with special attention with oral hygiene (Minhas et al., 2008).

CRAL, W. G.; TUCUNDUVA, R. A.; DAMANTE, J. H.; YAEDÚ, R. Y. F.; SOARES, M. Q. S.; CAPELOZZA, A. L. A.; OLIVEIRA, D. T. \& RUBIRA, C. M. F. Tratamiento conservador de osteomielitis crónica asociada con displasia ósea florida. Int. J. Odontostomat., 13(3):275-278, 2019.

RESUMEN: La displasia ósea florida (DOF) es una forma de displasia del tejido óseo donde el hueso trabecular normal es sustituido por tejido conectivo fibroso y por tejido mineralizado amorfo. En general, las lesiones son de origen asintomático y los pacientes deben ser controlados con exámenes clínicos. Sin embargo, debido a la vascularización deficiente de la lesión y el trauma local, pueden ocurrir lesiones secundarias y osteomielitis. Los pacientes pueden presentar dolor, ulceración de la mucosa, lesión expuesta en la cavidad oral, fístula y edema. En estos casos, el diagnóstico adecuado y el tratamiento de la lesión es decisivo para estabilizar la salud y la calidad de la vida. El objetivo de este artículo fue presentar un caso de complicación secundaria crónica de la osteomielitis tratada con tratamiento conservador. Una paciente de 68 años de edad, negra, informa de "hinchazón de las encías" que presentaba durante once años, con episodios de dolor. En el examen intra-oral se observó una pápula con supuración en la mucosa alveolar del lado derecho de la mandíbula. Además de la radiografía panorámica y tomografía computarizada de haz cónico (TCHC) se tomaron muestras de la lesión debido a observación de hueso esclerótico. El paciente fue diagnosticado con una infección por osteomielitis en asociación con DOF y fue tratada con antibióticos, además de una cirugía curativa. En este artículo se presentaron la incidencia, el diagnóstico diferencial, el tratamiento y la prevención de los efectos secundarios de osteomielitis asociados con el DOF. La información de este trabajo podría ayudar a los dentistas en la aplicación del tratamiento indicado en casos similares.

PALABRAS CLAVE: enfermedades del hueso; Osteomielitis; diagnóstico por imagenología.

\section{REFERENCES}

Abramovitch, K. \& Rice, D. D. Benign fibro-osseous lesions of the jaws. Dent. Clin. North Am., 60(1):167-93, 2016.

Alsufyani, N. A. \& Lam, E. W. Osseous (cemento-osseous) dysplasia of the jaws: clinical and radiographic analysis. J. Can. Dent. Assoc., 77:b70, 2011.

Barnes, L. E. J.; Reichart, P. \& Sidransky, D. Pathology and Genetics of Head and Neck Tumours. World Health Organization. Classification of Tumours. Lyon, IARC Press, 2005

Bencharit, S, D.; Schardt-Sacco, D.; Zuniga, J. R. \& Minsley, G. E. Surgical and prosthodontic rehabilitation for a patient with aggressive florid cementoosseous dysplasia: a clinical report. J. Prosthet. Dent., 90(3):220-4, 2003.

Dagistan, S.; Tozoglu, Ü.; Göregen, M. \& Çakur, B. Florid cemento-osseous dysplasia: A case report. Med. Oral Patol. Oral Cir. Bucal., 12(5):348-50, 2007.

Das, B. K.; Das, S. N.; Gupta, A. \& Nayak, S. Florid cemento-osseous dysplasia. J. Oral Maxillofac. Pathol., 17(1):150, 2013.

de Noronha Santos Netto, J.; Machado Cerri, J.; Miranda, A. M. \& Pires, F. R. Benign fibro-osseous lesions: clinicopathologic features from 143 cases diagnosed in an oral diagnosis setting. Oral Surg. Oral Med. Oral Pathol. Oral Radiol., 115(5):e56-65, 2013.

Gaetti-Jardim Júnior, E.; Fardin, A. C; Gaetti-Jardim, E. C.; de Castro, A. L; Schweitzer, C. M \& Avila-Campos, M. J. Microbiota associated with chronic osteomyelitis of the jaws. Braz. J. Microbiol., 41(4):1056-64, 2010.

Kutluay Köklü, H.; Cankal, D. A.; Bozkaya, S.; Ergün, G. \& Bar, E. Florid cemento-osseous dysplasia: Report of a case documented with clinical, radiographic, biochemical and histological findings. J. Clin. Exp. Dent., 5(1):e58-61, 2013.

MacDonald-Jankowski, D. S. Fibro-osseous lesions of the face and jaws. Clin. Radiol., 59(1):11-25, 2004.

Melrose, R. J.; Abrams, A. M. \& Mills, B. G. Florid osseous dysplasia. A clinicalpathologic study of thirty-four cases. Oral Surg. Oral Med. Oral Pathol., 41(1):62-82, 1976.

Minhas, G.; Hodge, T. \& Gill, D. S. Orthodontic treatment and cemento-osseous dysplasia: a case report. J. Orthod., 35(2):90-5, 2008.

More, C. B.; Shirolkar, R.; Adalja, C. \& Tailor, M. N. Florid cement-osseous dysplasia of maxilla and mandible: a rare clinical case. Braz. J. Oral Sci., 11(4):513-7, 2012.

Oliveira, M. T. F.; Cardoso, S. V. ; Silva, C. J.; Zanetta-Barbosa, D. \& Loyola, A. M. Failure of dental implants in cemento-osseous dysplasia: a critical analysis of a case. Rev. Odontol. UNESP, 43(3):223-7, 2014.

Sadda, R. S. \& Phelan, J. Dental management of florid cemento-osseous dysplosia. N. Y. State Dent. J., 80(3):24-6, 2014

Sarmento, D. J.; Monteiro, A. M.; de Medeiros, A. M. \& da Silveira, E. J. Severe florid cemento-osseous dysplasia: a case report treated conservatively and literature review. Oral Maxillofac. Surg., 17(1):43-6, 2013.

Schneider, L. C. \& Mesa, M. L. Differences between florid osseous dysplasia and chronic diffuse sclerosing osteomyelitis. Oral Surg. Oral Med. Oral Pathol., 70(3):308-12, 1990.

Schneider, L. C.; Mesa, M. L. \& Brickman, J. H. Complications of endodontic therapy in florid osseous dysplasia. Oral Surg. Oral Med. Oral Pathol., 64(1):114-6, 1987

Smieja, M. Current indications for the use of clindamycin: A critical review. Can. J. Infect. Dis., 9(1):22-8, 1998.

Corresponding author:

Wilson Gustavo Cral

Bauru School of Dentistry - Department of Stomatology

University of São Paulo

Al. Octávio Pinheiro Brisola, 9-75

Zip Code - 17012-901

Cidade Universitária

Bauru - São Paulo - BRAZIL

E-mail:wgcral@gmail.com 